\title{
Оцінювання фізичного стану дітей 5-6 років, які займаються оздоровчим фітнесом з елементами спортивних танців
}

\author{
УдК 616-056.2-053.4:796.035.012.265 \\ О. В. Андрєєва, А. О. Чеверда
}

Національний університет фізичного виховання і спорту України, Київ, Україна

Резюме. Мета. Оцінити показники фізичного стану дітей 5-6 років як основи розробки оздоровчих фітнес-занять з елементами спортивних танців. Матеріал і методи. Досліджено 65 дітей 5-6 років. Здійснено аналіз даних антропометричних показників. Використано педагогічні, емпіричні, інструментальні методи дослідження та проведено статистичну обробку емпіричних даних. Результати. Обґрунтовано та проаналізовано вплив оздоровчих фітнес-занять з елементами спортивних танців на рівень фізичного стану дітей 5-6 років, встановлено їх функціональний стан. Визначено, що нормальне співвідношення маси й довжини тіла дітей у більшості випадків властиве для дітей 6 років, натомість у 5 років вони характеризуються недостатньою масою тіла. Виявлено, що діти 5-6 років, які займаються спортивними танцями, мали мезоморфний тип тілобудови, нормальну або знижену масу тіла, вирізнялися дещо завузькою грудною кліткою і не мали статистично значущих відмінностей між показниками фізичного розвитку залежно від статі. Висновки. Результати педагогічного дослідження підтвердили, що у цілому заняття спортивними танцями мали позитивний вплив на рівень фізичного стану дітей 5-6 років.

Ключові слова: діти 5-6 років, спортивні танці, фізичний стан, функціональний стан, роботоздатність.

Evaluation of the physical condition of children 5-6 years concerned for healthy fitness with the elements of sports dances

O. V. Andreeva, A. O. Cheverda

National University of Physical Education and Sports of Ukraine, Kiev, Ukraine

Abstract. Goal. To evaluate the physical condition of children 5-6 years old as the basis for the development of health-improving fitness classes with elements of sports dancing. Materials and methods. The study involved 65 children 5-6 years old, analyzed anthropometric indicators, used pedagogical, empirical, instrumental research methods and carried out statistical processing of empirical data. Results. The effect of health-improving fitness classes with elements of sports dancing on the level of the physical condition of children 5-6 years old is justified and analyzed, the functional state of children 5-6 years old engaged in sports dancing is established. It was found that the normal ratio of the weight and body length of children in most cases is characteristic of children 6 years old, but in 5 years they are characterized by insufficient body weight. Found that children 5-6 years old, who are engaged in sports dancing, had a mesomorphic body type, normal or reduced body weight, had a slightly narrow chest and did not have statistically significant differences between the indicators of physical development depending on gender. Conclusions. The results of the pedagogical study confirmed that, in general, sports dance classes had a positive effect on the level of physical condition of children 5-6 years old.

Key words: children 5-6 years old, sports dancing, physical condition, functional state, working capacity. 
Постановка проблеми. Актуальність і доцільність дослідження проблеми здоров'я дітей зумовлені посиленням соціального запиту на здорову українську націю, усвідомленням необхідності підвищувати рухову підготовленість, формувати стійкі мотиви до занять фрізичними вправами та самостійного здійснення оздоровчорекреаційної діяльності $[1,9]$. Зазначене актуалізує пошук ефективних шляхів оздоровлення i гармонійного розвитку дітей та підлітків, підвищення рівня їх фрізичної підготовленості, i, що дуже важливо, - інтересу до занять. Одним із найпопулярніших видів рухової активності серед дошкільного контингенту $є$ спортивний танець [5, $7,12]$. Заняття спортивними танцями $€$ важливим чинником не тільки збереження здоров'я підростаючого покоління, а й засобом гармонійного фрізичного розвитку, покращення рівня фрізичного та емоційного стану дітей $[4,8,11]$. У той же час більшість авторів наголошують на необхідності визначення впливу фітнес-занять з елементами спортивних танців на розвиток фрізичного стану дітей 5-6 років $[2,6,15]$, що визначає актуальність дослідження у цьому напрямі.

Дослідження виконано відповідно до зведеного плану наукової роботи НУФВСУ на 20162020 рр. згідно 3 темою кафедри здоров'я, фрітнесу та рекреації «Теоретико-методологічні засади оздоровчо-рекреаційної рухової активності різних груп населення» (номер держреєстрації 0116U001630).

Мета дослідження - оцінити показники фізичного стану дітей 5-6 років як основи розробки оздоровчих фрітнес-занять з елементами спортивних танців.

Матеріал та методи дослідження: теоретичний аналіз фрахової науково-методичної літератури, педагогічні (педагогічний експеримент), антропометричні (оцінка соматометричних показників), фрізіологічні (оцінка фрізичної роботоздатності, показників серцево-судинної та дихальної систем) методи дослідження, методи математичної статистики. У педагогічному дослідженні взяли участь 65 дітей віком 5-6 років, які займаються спортивними танцями на етапі початкової підготовки. Дослідження проводилось на базі спортивного клубу «Супаданс» (Київ) 3 використанням антропометричних, емпіричних, педагогічних методів дослідження.

Результати дослідження та їх обговорення. Задля врахування особливостей фрізичного стану дітей старшого дошкільного віку нами було здійснено оцінку показників фрізичного розвитку, Досліджуючи показники фрізичного розвитку дітей 5-6 років, які займаються спортивними тан-

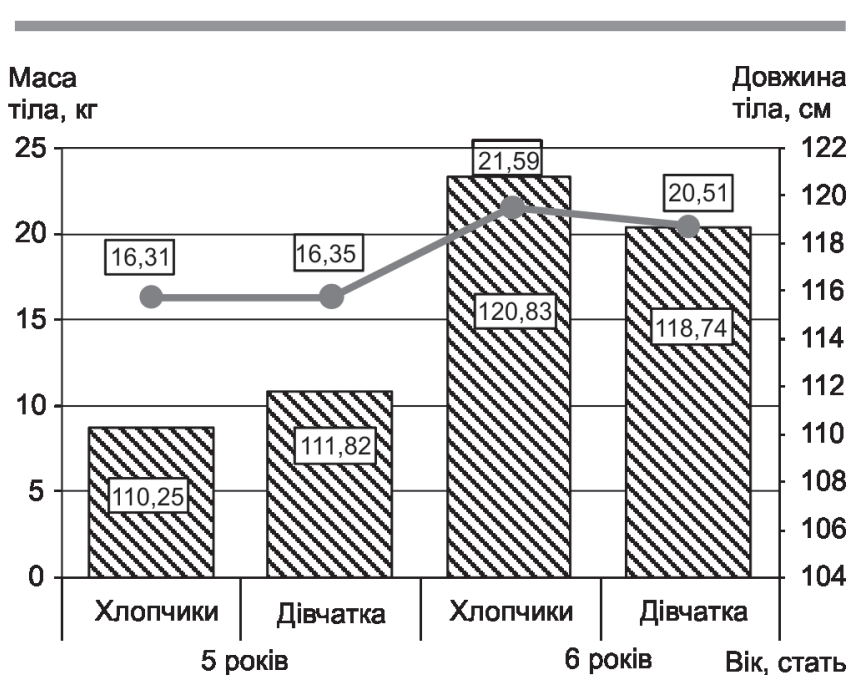

Рисунок 1 - Аналіз масо-зростових показників фізичного розвитку дітей 5-6 років, котрі займаються спортивними танцями $(n=65)$ :

NIV - довжина тіла; - - - маса тіла

цями, ми помітили, що середні значення довжини тіла дівчаток 5 років на $1,41 \%$ переважають показники хлопчиків даного віку, натомість у 6 років, навпаки, на $1,76 \%$ менші порівняно 3 хлопчиками (рис. 1).

Проте слід звернути увагу, що наявність статистично значущих $(p<0,05)$ відмінностей між показниками дівчаток і хлопчиків у кожній з вікових груп не виявлено.

У той же час середньостатистичні показники між групами дітей однієї статі залежно від віку статистично значуще $(p<0,05)$ зростають.

Розрахований і оцінений за перцентильними таблицями індекс маси тіла (IMT) дітей 5-6 років, що займаються спортивними танцями, показав, які як у дівчаток, так і у хлопчиків 5 років співвідношення маси й довжини тіла відповідали нижче середньому рівню, а в 6 років - встановленим віковим нормам, зазначеним у стандартних показниках фрізичного розвитку дітей (ВООЗ). Аналіз емпіричного матеріалу засвідчив, що у кожній з вікових груп показник IMT хлопчиків переважав даний показник у дівчаток: у 5 років зазначене перевищення становило 2,30\% $\left((13,42 ; 1,55) \mathrm{\kappa г} \cdot \mathrm{M}^{-2}\right.$ проти $\left.(13,11 ; 1,84) \mathrm{\kappa г} \cdot \mathrm{M}^{-2}\right)$, а в 6 років - $1,40 \%\left((14,76 ; 1,61) \mathrm{kг} \cdot \mathrm{M}^{-2}\right.$ проти $\left.(14,56 ; 1,51) \mathrm{kг} \cdot \mathrm{M}^{-2}\right)$. При цьому статистично значущих $(p>0,05)$ відмінностей між значенням показника в межах однієї вікової групи залежності від статі не доведено, утім як у дівчаток, так і у хлопчиків IMT статистично значуще $(p<0,05)$ збільшується з віком.

Виявилося, що нормальне співвідношення маси й довжини тіла в більшості випадків властиве для дітей 6 років, натомість у 5 років вони характеризуються недостатньою масою тіла (рис. 2). 
Рисунок 2 - Розподіл за співвідношенням маси й довжини тіла дітей, котрі займаються спортивними танцями за $(\mathrm{n}=65)$ : - вищий за середній; - середній; $\square-$ нижчий за середній; $\square-$ низький

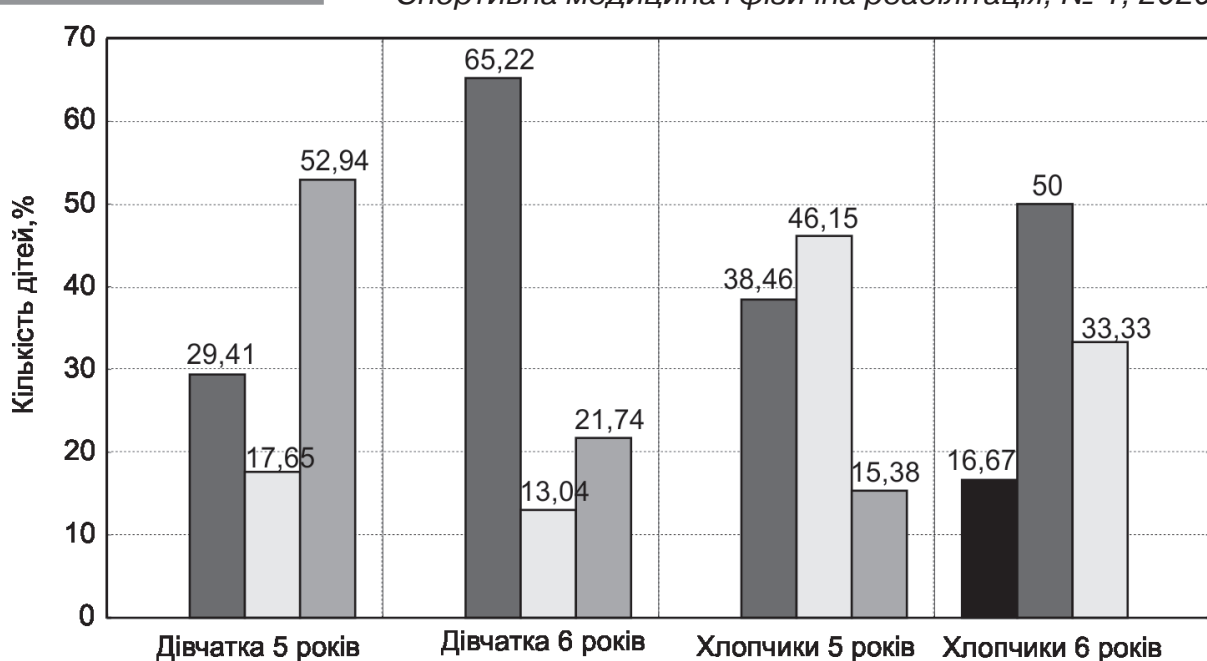

Слід звернути увагу на те, що загалом розподіл дітей 5-6 років за відношенням маси до довжини тіла $є$ співвіднесеним залежно від статі в кожній з вікових груп [3].

У процесі аналізу обхвату грудної клітки дітей з'ясувалося, що в 5-річному віці показник ОГК хлопчиків на 0,90 \% менший порівняно 3 дівчатками, однак у 6 років на $1,99 \%$ ОГК хлопчиків переважає даний показник у дівчаток (табл. 1).

Слід звернути увагу, що статистично значущих $(p<0,05)$ відмінностей між показниками ОГК дітей в межах однієї вікової групи залежно від статі не встановлено. Водночас, із віком простежується статистично значуще $(p<0,05)$ збільшення досліджуваного показника, яке в дівчаток становило 2,30, а в хлопчиків $1,40 \%$ порівняно з 5- і 6-річними дітьми.

Індекс Рорера у дівчаток 5 років коливався від 9,35 до $15,03 \mathrm{\kappa г}^{\cdot} \mathrm{m}^{-3}$ і в середньому становив $(11,72 ; 1,63) \mathrm{\kappa г} \cdot \mathrm{M}^{-3}$, а в 6 років відбувся приріст показника на $4,70 \%$ і його середнє значення зросло до $(12,27 ; 1,33) \mathrm{kг} \cdot \mathrm{M}^{-3}$. У хлопчиків 5 і 6 років середні показники становили відповідно $(12,18 ; 1,32)$ та $(12,22 ; 1,33) \mathrm{\kappa} \cdot \mathrm{M}^{-3}$. Зазначимо, що в усіх групах обстежених дітей значення індексу Рорера відповідало нормі, яка коливається в межах від 10,7 до 13,7 кг $\mathrm{m}^{-3}$. Такі результати свідчать про те, що в цілому досліджувані мали гармонійний фрізичний розвиток. Необхідно вказати, що як і у випадку IMT, не зважаючи на

ТАБЛИЦЯ 1 - Аналіз обхвату грудної клітки дітей 5-6 років $(n=65)$

\begin{tabular}{|c|c|c|c|c|}
\hline Стать & Вік. років & $\min -\max$ & $-\mathbf{x}$ & $\mathbf{s}$ \\
\hline \multirow{2}{*}{ Дівчатка $(n=40)$} & $5(n=17)$ & {$[53-62]$} & 59,03 & 2,26 \\
\cline { 1 - 5 } & $6(n=13)$ & {$[57-68]$} & 60,87 & 2,56 \\
\hline \multirow{2}{*}{ Хлопчики $(n=25)$} & $5(n=23)$ & {$[53,5-63]$} & 58,50 & 2,89 \\
\cline { 2 - 5 } & $6(n=12)$ & {$[59-66]$} & 62,08 & 2,35 \\
\hline
\end{tabular}

окремі відмінності між показником залежно від статі (у 5 років - 3,93\% на користь хлопчиків, а у 6 років - 0,45\% на користь дівчат), статистично значущих $(p>0,05)$ розходжень не доведено. Крім того, статистично значущі $(p>0,05)$ відмінності відсутні й між показниками дітей однієї статі, але різного віку.

Зауважимо, що в даному випадку оцінка відмінностей відбувалась за допомогою критерію Манна-Уітні [2] як для даних, що не підлягають нормальному закону розподілу.

Згідно з отриманими даними, серед обстежених превалювали діти з гармонійним фрізичним розвитком. Серед 5-річних дівчаток їх частка становила 58,82 \%, а серед 6-річних - 69,57 \%. 3-поміж хлопчиків обох груп частка з гармонійним розвитком виявилася ще більшою - 76,92 і $66,67 \%$ у 5 і 6 років відповідно, утім встановлені відмінності в розподілах не були статистично значущими $(p>0,05)$. Порівнюючи частки дітей з дисгармонійним фрізичним розвитком, з'ясувалося, що відсоток негармонійно розвинених дітей за рахунок недостатньої маси тіла переважав відсоток дітей негармонійно розвинених за рахунок надлишкової маси тіла: у дівчаток 5 років на $29,41 \%(35,29$ проти $5,88 \%), 6$ років - на $13,04 \%$ (21,74 проти 8,70\%); у хлопчиків 5 років - на 7,69 \% (15,38 проти 7,69\%), 6 років - на $16,67 \%$ (25,0 проти $8,33 \%)$ (рис. 3).

Аналіз індексу Ерісмана [14] в обстежених дозволив встановити, що в них недостатньо розвинена грудна клітка, причому в 6 років збільшується частка дітей з від'ємним значенням показника. Так, якщо в дівчаток 5 років таких налічувалося $17,65 \%(n=3)$ й медіанне значення становило $(3,5 ; 2,5 ; 4)$ ум. од., то в 6 років їх частка зросла до $34,78 \%$, а медіанне значення індексу зменшилося до $(1 ; 0 ; 3,5)$ ум. од. У хлоп- 

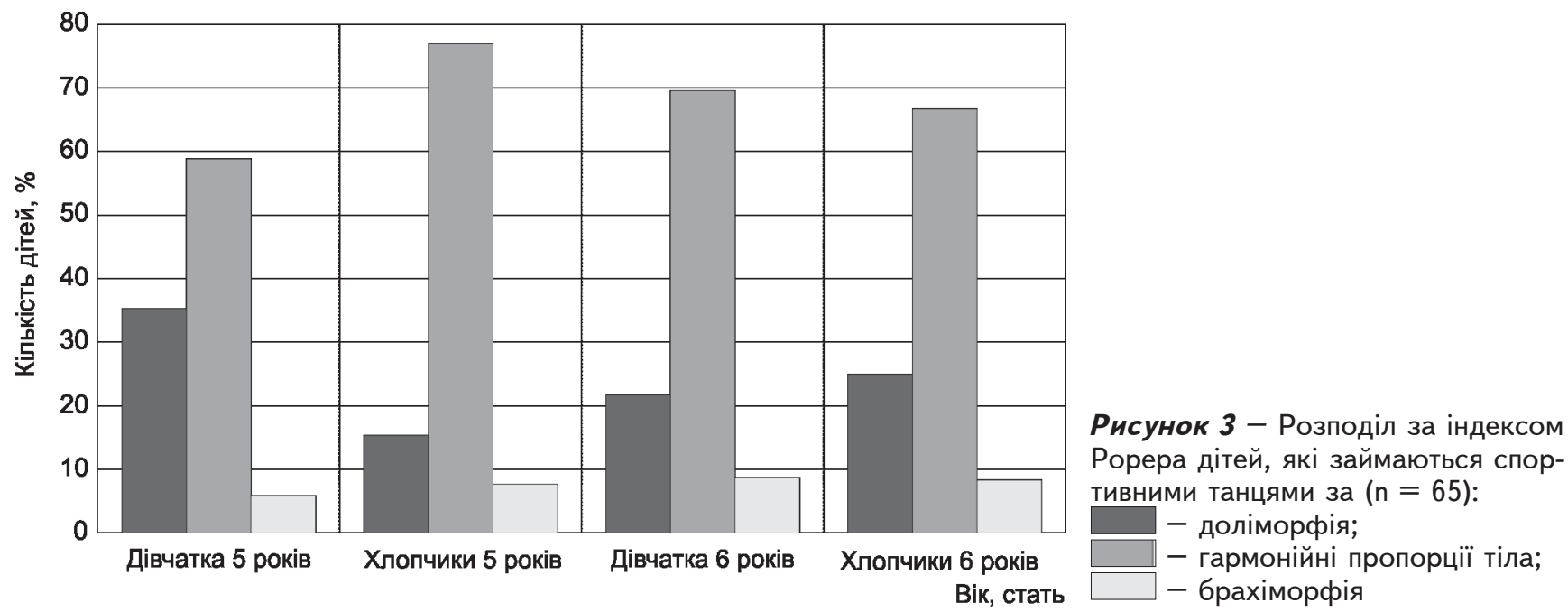

чиків ситуація була наближеною: в 5-річному віці налічувалось $15,38 \%(n=2)$ з від'ємним значенням індексу Ерісмана, який становив $(3,5 ; 3 ; 4,5)$ ум. од., а в 6 -річному $-25,0 \%(n=3)$, що зумовило зменшення медіанного значення показника до $(1,5 ; 1 ; 3,5)$ ум. од.

Розрахований індекс пропорційності (за методикою О. Д, Дубогай [13]), який становив в 5 років $(36,41 ; 4,02)$ ум. од. та $(35,27 ; 2,98)$ ум. од. та в 6 років $(37,36 ; 3,29)$ ум. од. та $(37,16 ; 3,71)$ ум. од. у дівчаток і хлопчиків відповідно, підтвердив слабку й дуже слабку тілобудову обстежених дітей.

Так само й середньостатистичні значення індексу Бругша свідчать про наявність серед дітей помітної частки з вузькою грудною кліткою. Причому, згідно з інтерпретацією зазначеного індексу, 5-річні діти мають більш розвинену грудну клітку порівняно з 6-річними. Виявилося, що в дівчаток 5 років середнє значення становило $(52,79 ; 2,24)$ ум. од. й 23,53 \% (n=4) з-поміж них характеризуються вузькою грудною кліткою, а в 6 років середнє значення індексу зменшилося до $(51,26 ; 1,69)$ ум. од., а частки дітей 3 вузькою грудною кліткою зросла до 73,91 \% ( $\mathrm{n}=17)$. У 5-річному віці серед хлопчиків зареєстровано $15,38 \%(n=2)$ з вузькою грудною кліткою, а середнє значення індексу Бругша становило $(53,14 ; 1,87)$ ум. од., а в 6 -річному таких хлопчиків налічувалося $58,33 \%(n=7)$, що знайшло своє відображення в зменшенні середнього значення показника до $(51,40 ; 1,97)$ ум. од.

Середні показники індексу Вервека-Воронцова у 5-річних дівчаток становили $(1,22$; $0,08)$ ум. од., а в 6 -річних - $(1,17 ; 0,06)$ ум. од. У хлопчиків зафріксовано середньостатистичні показники на рівні $(1,21 ; 0,07)$ ум. од. у 5 років та $(1,15 ; 0,06)$ ум. од. у 6 років.
Аналіз індексу Вервека-Воронцова [10] показав превалювання мезоморфного типу тілобудови у обстежених: серед 5-річних дітей їх частка становила 64,71 та $69,23 \%(1,22 ; 0,08)$ ум. од., а серед 6-річних відсоток дітей з вказаним типом тілобудови становив $95,65 \%(n=22)$ та $100 \%$ ( $n=12)$ у дівчаток і хлопчиків відповідно. Усі інші діти характеризувалися помірною доліморфрією, що підтверджує дані про слабку й дуже слабку тілобудову обстежених дітей, встановлену за індексом Дубогай.

Таким чином, у цілому діти 5-6 років, що займаються спортивними танцями, мали мезоморфний тип тілобудови, нормальну або знижену масу тіла, вирізнялися дещо завузькою грудною кліткою й не мали статистично значущих $(p>0,05)$ відмінностей між показниками фрізичного розвитку залежно від статі. А отримані розходження в розподілі дітей згідно з тими чи іншими індексами можна пояснити трансформацією уявлень про тотальні розміри тіла дітей 5-6 років з перебігом часу.

У ході оцінки й аналізу ЧСС обстежених дітей виявилося, що якщо в 5 років статистично значущих $(p>0,05)$ відмінностей між величиною показника в дівчаток і хлопчиків не спостерігається, то в 6 років у хлопчиків порівняно з дівчатками статистично значуще $(p<0,05)$ менша ЧСС (табл. 2).

Крім того, для встановлення функціонального стану дітей 5-6 років, котрі займаються спортивними танцями, вимірювався систолічний та діастолічний артеріальний тиск (АТ). Результати обстеження представлено в таблиці 3. Виявлено, що показники систолічного АТ дівчаток статистично значуще $(p>0,05)$ не відрізняються від показників хлопчиків, а також у обох статевих групах за віком не мають статистично значущих $(p>0,05)$ відмінностей. 
ТАБЛИЦЯ 2 - Аналіз ЧСС дітей 5-6 років, уд $\cdot \mathbf{x в}^{-1}$ $(\mathrm{n}=65)$

\begin{tabular}{|c|c|c|c|c|}
\hline Стать & Вік, років & $\min -\mathbf{m a x}$ & $\overline{\mathbf{x}}$ & $\mathbf{s}$ \\
\hline Дівчатка $(\mathrm{n}=40)$ & $5(\mathrm{n}=17)$ & {$[78-102]$} & 90,13 & 7,67 \\
\cline { 1 - 5 } & $6(\mathrm{n}=13)$ & {$[80-102]$} & 92,26 & 5,98 \\
\hline Хлопчики $(\mathrm{n}=25)$ & $5(\mathrm{n}=23)$ & {$[70-104]$} & 89,00 & 9,26 \\
\cline { 2 - 5 } & $6(\mathrm{n}=12)$ & {$[75-94]$} & 87,17 & 5,57 \\
\hline
\end{tabular}

ТАБЛИЦЯ 3 - Аналіз артеріального тиску дітей 5-6 років, мм рт. ст. $(\mathrm{n}=65)$

\begin{tabular}{|c|c|c|c|c|}
\hline Стать, показник & Вік, років & $\min -\max$ & $\overline{\mathbf{x}}$ & $\mathbf{s}$ \\
\hline \multirow{2}{*}{$\begin{array}{l}\text { Дівчатка } \\
(\mathrm{n}=40), \mathrm{AT}_{\text {сист }}\end{array}$} & $5(n=17)$ & [85-110] & 95,94 & 6,49 \\
\hline & $6(n=13)$ & {$[86-111]$} & 98,57 & 6,34 \\
\hline \multirow{2}{*}{$\begin{array}{l}\text { Хлопчики } \\
(\mathrm{n}=25), \mathrm{AT}_{\text {сист }}\end{array}$} & $5(n=23)$ & {$[92-106]$} & 98,77 & 4,76 \\
\hline & $6(n=12)$ & [94-109] & 101,42 & 4,87 \\
\hline \multirow{2}{*}{$\begin{array}{l}\text { Дівчатка } \\
(\mathrm{n}=40), \mathrm{AT}_{\text {діаст }}\end{array}$} & $5(n=17)$ & [53-68] & 59,44 & 3,90 \\
\hline & $6(n=13)$ & [52-70] & 60,04 & 4,45 \\
\hline \multirow{2}{*}{$\begin{array}{l}\text { Хлопчики } \\
(\mathrm{n}=25), \mathrm{AT}_{\text {діаст }}\end{array}$} & $5(n=23)$ & [57-69] & 62,38 & 4,11 \\
\hline & $6(n=12)$ & [60-71] & 64,08 & 4,06 \\
\hline
\end{tabular}

Водночас, діастолічний АТ хлопчиків як 5 , так і 6 років статистично значуще $(p<0,05)$ перевищує вказаний показник у дівчаток, проте статистично значуще $(p>0,05)$ не відрізняється в рамках статевих груп за віком. Варто вказати, що відмінності між показниками функціонального стану оцінювалися за допомогою критерію Стьюдента для незалежних вибірок, оскільки вихідні дані підлягали нормальному закону розподілу.

Визначення рівня обмінно-енергетичних процесів, що відбуваються в організмі дітей, здійснювали на основі розрахунку й аналізу індексу Робінсона. 3'ясувалося, у 5 років середньо-групове значення показника дівчаток становило $(86,32 ; 7,69)$ ум. од., що на $1,95 \%$ менше, ніж середні результати хлопчиків даного віку, які становили $(88,00 ; 10,89)$ ум. од. У 6 років ситуація виявилась протилежною: вже у дівчаток середній показник у $(91,19 ; 10,88)$ ум. од. на 3,07 \% переважає середній показник хлопчиків, який визначено на рівні $(88,40 ; 6,93)$ ум. од. Однак треба звернути увагу, що статистично значуще $(p>0,05)$ показники в межах однієї вікової групи залежно від статі, а також однієї статі залежно від віку не відрізнялися.

Розподіл дітей за рівнем стану регуляції серцево-судинної системи показав зниження максимальних аеробних можливостей організму в переважної більшості дітей, зокрема нижчий за середній рівень констатовано в 64,71 та 61,54\% дівчатоок і хлопчиків 5 років. При цьому частка дітей з недостатнім рівнем стану регуляції ССС збільшується з віком і досягає 73,91 та 75,00\% у дівчаток та хлопчиків 6 років (рис. 4).

Оцінка індексу Кердо [5] дозволила виявити перевагу симпатичної регуляції тонусу судин у всіх групах дітей, котрі брали участь у експерименті. При цьому і у 5 , і у 6 років середні показники дівчаток перевищують показники хлопчиків: в 5 років - на $13,11 \%((33,62 ; 7,15)$ проти $(29,21 ; 8,60)$ ум. од.); у 6 років - на $25,05 \%$ $((34,90 ; 2,87)$ проти $(26,16 ; 7,21)$ ум. од.). Крім того, якщо в 5 років ці відмінності не були статистично значущими ( $p>0,05)$, то в 6 років індекс Кердо дівчаток виявився статистично значуще ( $<<0,05)$ більшим порівняно з хлопчиками.

Водночас спостерігались знижені показники індексу Руф'є, що вказує на недостатню фрізичну роботоздатність дітей 5-6 років, які займаються спортивними танцями. Встановлено, що в 5-річному віці середньогрупова величина індексу Руф'є у хлопчиків на $1,13 \%((11,24 ; 1,92)$ проти $(11,11 ; 2,30)$ ум. од.) перевищує вказаний показник дівчаток, що свідчить про знижену фізичну роботоздатність хлопчиків порівняно з дівчатками, а в 6 років навпаки, у хлопчиків на 2,49\% $(((11,12 ; 2,16)$ проти $(11,40 ; 2,29)$ ум. од.)) біль-
Рисунок 4 - Розподіл дітей 5-6 років за індексом Робінсона $(\mathrm{n}=65)$ : - вище за сердній;

- середній;

- нижчий за середній

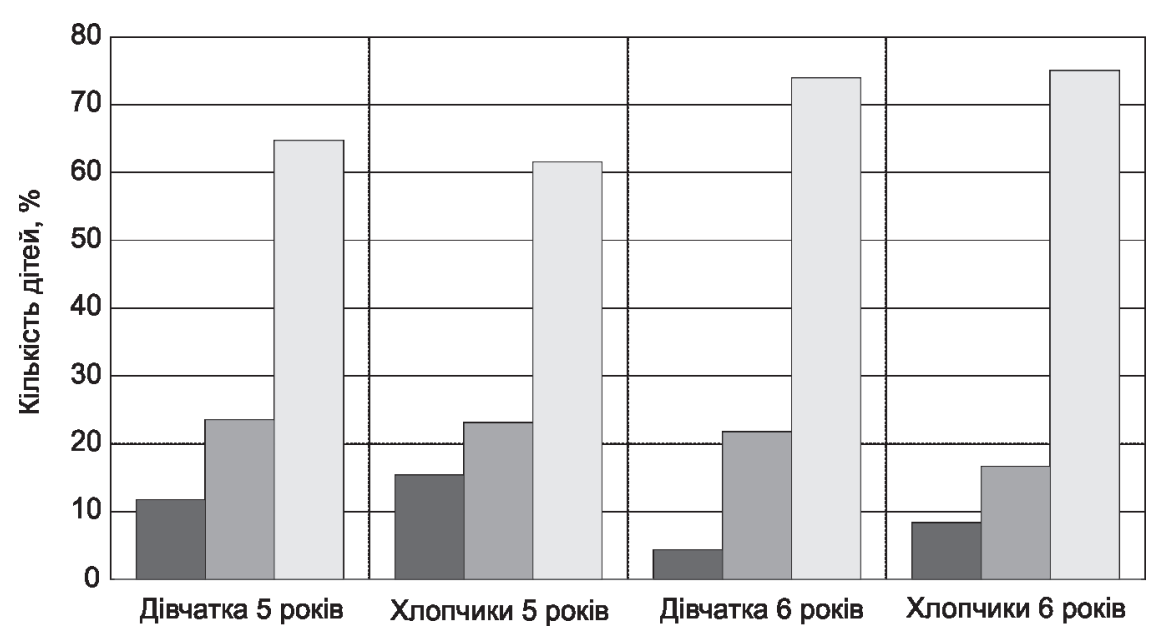




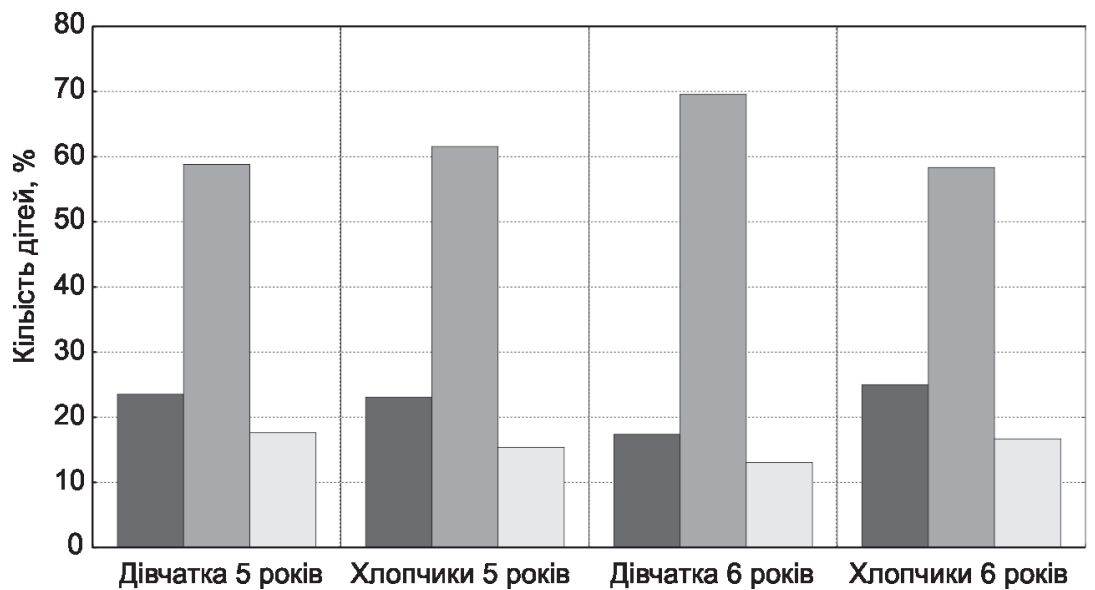

Рисунок 5 - Розподіл дітей 5-6 років за індексом Руф'є $\epsilon(\mathrm{n}=65)$ : $\square-$ середній; $\square-$ нижчий за середній; $\square-$ низький ше середнє значення індексу, ніж у дівчаток. Варто звернути увагу, що виявлені відмінності не мали статистичної значущості $(p>0,05)$ як у порівнянні хлопчиків і дівчат одного віку, так і у порівнянні дівчаток 5 і 6 років та хлопчиків 5 і 6 років. Отже, значення індексу Руф'є у дітей 5-6 років свідчить про зниження їх фрізичної роботоздатності, причому з віком тенденції до покращення функціонального резерву серця не простежується.

Зауважимо, що переважна частка дітей характеризується нижчим за середній рівнем функціонального резерву серця: у 5 років їх питома вага становила 58,82 і $61,54 \%$, а в 6 років 69,57 і $58,33 \%$ у дівчат і хлопчиків відповідно (рис. 5).

Водночас частки дітей із середнім та низьким рівнем фрізичної роботоздатності виявилися співвіднесеними, а дітей з вищим за середній та високим рівнем функціонального резерву серця серед обстежених не зареєстровано.

Дослідження адаптаційного потенціалу (АП) дітей 5-6 років, котрі займаються спортивними танцями за методикою Р. М. Баєвського, засвідчило, що діти в цілому характеризуються задовільною адаптацією. Середні показники у 5 років становили $(1,75 ; 0,13)$ та $(1,82 ; 0,16)$ ум. од. і в 6 років $(1,81 ; 0,18)$ та $(1,81 ; 0,12)$ ум. од. у дівчаток і хлопчиків відповідно. Стосовно перевірки адаптаційно-резервних можливостей (AMP), яка базується на оцінці окремих ланок загального адаптаційного потенціалу, то вона засвідчила наявність значної частки дітей зі зниженим рівнем AMP з-поміж обстежених. У цілому для дітей 5 - 6 років властива середня оцінка AMP, що вказує на напруження в них механізмів адаптації. У кожній з підгруп середні показники хлопчиків перевищували середні показники дівчаток: в 5 років - на 19,92 \% ((1,95; 0,56) проти $(1,63$;
0,42) ум. од.), у 6 років - на $17,13 \%((1,83$ $0,48)$ проти $(1,57 ; 0,34)$ ум. од.), проте ці відмінності не є статистично значущими ( $>>0,05)$.

Оцінку стану дихальної системи дітей 5-6 років здійснювали за допомогою проб Штанге й Генче. Дослідження показало, що в хлопчиків 5 років середній показник затримки дихання на вдиху на 8,01 \% перевищує аналогічний показник у дівчаток, а в 6 років у хлопчиків на 8,86\% більший. При цьому час затримки дихання на видиху в хлопчиків 5 років переважає показник дівчаток на 8,45 \%, а в 6 років ці відмінності становлять 10,04 \% на користь хлопчиків (табл. 4).

Незважаючи на окремі відмінності в показниках, дослідження показало відсутність статистично значущих $(p>0,05)$ відмінностей між показниками дівчаток і хлопчиків, проте як у дівчаток, так і у хлопчиків 6 років показники Штанге й Генче статистично значуще $(p<0,05)$ більші порівняно з дітьми 5 років.

Висновки. Встановлено, що нормальне співвідношення маси й довжини тіла дітей у більшості випадків властиве для дітей 6 років, натомість у 5 років вони характеризуються недостатньою масою тіла. Проте слід звернути увагу, що наявність статистично значущих відмінностей між

ТАБЛИЦЯ 4 - Аналіз стану дихальної системи дітей 5-6 років, $c(n=65)$

\begin{tabular}{|l|c|c|c|c|}
\hline \multicolumn{1}{|c|}{ Стать, показник } & Вік, років & min-max & $\overline{\mathbf{x}}$ & $\mathbf{s}$ \\
\hline $\begin{array}{l}\text { Дівчатка }(n=40), \\
\text { проба Штанге }\end{array}$ & $5(n=17)$ & {$[7-12]$} & 9,19 & 1,52 \\
\cline { 2 - 5 } $\begin{array}{l}\text { Хлопчики }(n=25), \\
\text { проба Штанге }\end{array}$ & $5(n=23)$ & {$[11-17]$} & 14,39 & 11,43 \\
\cline { 2 - 5 } & $6(n=12)$ & {$[13-19]$} & 15,67 & 1,32 \\
\hline $\begin{array}{l}\text { Дівчатка }(n=40), \\
\text { проба Генче }\end{array}$ & $5(n=17)$ & {$[4-9]$} & 6,31 & 1,62 \\
\cline { 2 - 5 } $\begin{array}{l}\text { Хлопчики }(n=25), \\
\text { проба Генче }\end{array}$ & $5(n=13)$ & {$[8-14]$} & 11,43 & 1,85 \\
\cline { 2 - 6 } & $6(n=12)$ & {$[5-9]$} & 6,85 & 1,34 \\
\hline
\end{tabular}


показниками дівчаток і хлопчиків у кожній з вікових груп не виявлено. У процесі аналізу обхвату грудної клітки дітей з'ясувалося, що в 5-річному віці показник ОГК хлопчиків на 0,90\% менший порівняно з дівчатками, однак у 6 років на 1,99\% ОГК хлопчиків переважає даний показник у дівчат. Виявлено, що діти 5-6 років, які займаються спортивними танцями, мали мезоморфний тип тілобудови, нормальну або знижену масу тіла, вирізнялися дещо завузькою грудною кліткою й не мали статистично значущих відмінностей між показниками фрізичного розвитку залежно

\section{Література}

1. Бланин АА. Становление физических качеств дошкольников в зависимости от их двигательной активности и соматотипа [The formation of physical qualities of preschoolers depending on their physical activity and somatotype] [Дисертация]. Малаховка; 2000. 157 c.

2. Воронцова ИЛ, Прокопьев НЯ, Колунин ЕТ. Оценка физического развития методом индексов мальчиков периода второго детства г. Тюмени с нарушением прикуса и дефектами речи на начальном этапе занятий спортом [Assessment of physical development by the method of indexes of boys from the second childhood of Tyumen with malocclusion and speech defects at the initial stage of playing sports]. Молодой ученьй. 2014; 5: 1327. - URL https://moluch.ru/archive/64/9508/

3. Дворкина НН, Дворкин ЛС, Куприна НК. Здоровьесберегающие игровые технологии в процессе развития физических способностей и мышления детей старшего дошкольного возраста [Health-saving gaming technologies in the development of physical abilities and thinking of older preschool children]. Научно-практический журнал «Здоровьесберегающее образование». 2012; 3 (23): 111-6.

4. Жук Г, Хабінець Т. Вплив занять аквафітнесом на функціональний стан дітей молодшого шкільного віку [Influence of aqua fitness classes on the functional status of young school children]. Історичні, теоретикометодичні, медико-біологічні аспекти фьізичної культури і спорту. Матеріали Всеукраїнської науково-практичної конференції (Чернівці, 6-7 квіт. 2016 р.) МОНУ, Чернівецький НУ ім. Ю. Федьковича,Чернівецьке обласне відділення НОК України. Чернівці; 2016. 29-34.

5. Назарова Е В, Кузмичев ЮГ, Жукова ЕА. Динамика показателей длины и массы тела детей дошкольного возраста [Dynamics of indicators of length and body weight of preschool children]. Педиатрия. 2014; 93, 1: 128-33.

6. Назмутдинова ВИ, Журавлева-Ярцева АА, Прокопьев НЯ. Некоторые показатели индексной оценки физического развития детей дошкольного возраста Нижнетавдинского района Тюменской области [Some indicators of the index assessment of the physical development of preschool children in the Nizhnetavdinsky district of the Tyumen region]. Молодой ученый. 2014; 20: 59-61. - URL https://moluch.ru/archive/79/14094/

7. Медведев ДВ. Физиологические факторы, определяющие физическую работоспособность человека в процессе многолетней адаптации к специфической мышечной деятельности [Physiological factors determining the physical performance of a person in the process of many years of adaptation to specific muscle activity]. Автореферат. Москва, 2007. 24 c.

trofimo4ka92@gmail.com від статі. Отримані розходження в розподілі дітей згідно з тими чи іншими індексами можна пояснити трансформацією уявлень про тотальні розміри тіла дітей 5-6 років з перебігом часу. Обгрунтовано та проаналізовано рівень функціонального стану серцево-судинної та дихальної систем дітей $5-6$ років.

Перспективи подальших досліджень полягають у вдосконаленні фотнес-програми з елементами спортивних танців, яка у подальшому може використовуватися як засіб підвищення рівня розвитку фрізичного стану дітей 5-6 років.

8. Мониторинг роста и развития детей 5 лет [Monitoring the growth and development of children 5 years old]. Руководство ВОЗ/ЮНИСЕФ Ташкент, 2013. 184 c

9. Семененко В. Вплив диференційованого застосування загартовуючих процедур на рівень фізичного стану молодших школярів [Influence of differentiated application of tempering procedures on the level of physical condition of younger students]. Молода спортивна наука України: 10 років (1996-2006) : збірник наукових праць з галузі фіз. культури та спорту: періодичне видання. Львів : Українські технології; 2006; 10, 1 80-4.

10. Слугина МА, Слугин ВА. Оценка функционального состояния сердечно-сосудистой системы человека в покое и при на80

грузках [Assessment of the functional state of the human cardiovascula system at rest and during exercise]. Лечебная ффизкультура и массаж. 2004; 10, 1: 14-20.

11. Солодков АС, Сологуб ЕБ. Физиология человека. Общая. Спортивная. Возрастная [Human physiology. The total. Athletic. Age]. - 2-е изд. Изд-во: Олимпия Пресс; 2005. 528 с

12. Фомин НА. Физическое воспитание детей дошкольного возраста на основе сюжетно-ролевой ритмической гимнастики [Physical education of preschool children on the basis of subject-role rhythmic gymnastics]. Монография. Волгоград: Издатель; 2004. 210 с.

13. Футорний С, Носова Н, Коломієць Т. Сучасні технології, які використовуються в процесі фізичного виховання і реабілітації при порушеннях постави і плоскостопості у дітей старшого дошкільного віку [Modern technologies used in the process of physical education and rehabilitation in disorders of posture and flat feet in older preschool children]. Слобожанський науково-спортивний вісник. 2017; 5(61): 104-9.

14. Футорний C, Носова Н, Коломієць Т. Особливості функціональних порушень опорно-рухового апарату дітей старшого дошкільного віку на сучасному етапі [Features of functional disorders of the musculoskeletal system of older preschool children at the present stage]. Науковий часопис НПУ імені М. П. Драгоманова. 2017; 8 (90): 58-62.

15. Ханкелдиева ХК, Абдуллаева МЭ, Тожибоев ТТ. Индексовые значения антропометрии у детей с бронхиальной астмой [Index values of anthropometry in children with bronchial asthma]. Молодой ученый. 2017; 25 : 200-202. - URL https://moluch.ru/archive/159/44925/

Надійшла 24.02.2020 